\title{
Decentralized Decision Making Practices in Chinese State-Owned Corporations
}

\author{
Ziguang CHEN ${ }^{1)}$ and Mitsuru WAKABAYASHI \\ (Graduate School of International Development, Nagoya University)
}

\begin{abstract}
This paper tries to explore the meaning of decentralized decision making practices by leaders in Chinese State-Owned Corporations (SOCs) and its relationship with corporate performance. As a result of sixteen years reform efforts, the management practices have been improved, due to the increased quality of the top managers in SOCs. The percentage of college graduates among top managers is $75 \%$ based for the sample of this study. Reforms have given more power to the top managers than before. Now, it enables them to contorl corporations more freely. However, the middle and lower-middle managers perceive that superiors hold too much power in their hands, as they seem to rely on centralized leadership style in the process of decision making. It was found that in the successful SOCs, managers seem to employ participative decision making practices under the decentralized leaders more often than those in the average perfoming SOCs. Moreover, it was found that managers at lower-middle positions working for the high performing SOCs are enjoying more participation and the higher quality leader-member exchange relations than other managers. This suggests that participation of young managers belonging to the After-Cultural Revolution generation, is one of the features of high performing SOCs in China.
\end{abstract}

\section{INTRODUCTION}

Since Raymond Miles introduced the term 'human resources' seperating from the human relations model in 1965, Human Resource Management (HRM) has become to be a more important subject world-wide in the recent ten years, both in management theories and as applied management practices (Pieper, 1990). In China, Human Resource Development (HRD) of management people plays a central role in its attempt to change the country's economy from a centralized planned system towards a more marketoriented economy. Development of the efficient management organization is becoming a key aspect of the current economic and administrative reform in China (Wang, 1990). These reforms are

1) Ziguang CHEN is a faculty of Hangzhou University, China, studing at the Graduate School of International Development, Nagoya University, supported by the Japan's Monbusho Scholarship. going to affect almost every aspect of management practices in Chinese corporations. One of the most important current development is a shift in leadership development practices from nominating political functionaries of the Communist Party to corporate leaders, to training and selecting professional managers for the corporate management positions based on their ability and performance. There are five significant changes that have taken place in Chinese management since 1982, which have brought great impacts upon HRM practices in Chinese state-owned corporations (SOCs) since then. (1) The power of the Communist Party has retreated from the corporate management and administrative processes. In return, the power of corporate top managers is increasing stronger and stronger. (2) The share of gross output value of the SOCs decreased from 75.9 percent in 1980 to 43.1 percent in 1993 , while the shares of collective-owned corporations, individual-owned corporations and other forms of corporations are getting larger significantly (SYOC. 1993, 1994). (3) Drafting and promulga- 
tion of the China's State-Owend Corporations' Law (in 1988) has introduced a great change in the economic and management environment for the SOCs. (4) Corporate culture and value systems in the SOCs have been changing gradually, with a decreasing emphasis on political ideology, but an increasing emphasis on profit and growth. Therefore, SOCs have been transformed to incorporate more aspects of market and organizational realities. (5) It is important to point out that the tradition of a close link between practitioners and researchers in China has remained unchanged, thus making research and training in the HRM related areas increasingly important to help SOCs adapt to the changing economic environment.

All of these changes show a rapid progress in China's economic and management reform programs. Especially, Chinese industrial management reform has reached to the stage where corporations are granted greater individual administrative authorities and are encouraged to build up their own resources (Xu, 1989). But, industry development has been considerably constrained by the lack of industrial management skills, and particularly managers' administrative skills in the SOCs (Warner, 1987). The reform of SOCs which started in 1979 under the slogan of "Four Modernizations" has not been as successful as reforms achieved in the private sector and township industry in terms of economic efficiency. The main problems for SOCs' reform at the present stage of development are among those as follows: (1) the low efficiency and finantial debts, (2) high percentage of defect products and low quality, and (3) a large number of surplus workers combined with a shortage of capital. According to the Chinese official estimation, there existed $34.4 \%$ SOCs suffering losses in 1994. The total losses of SOCs were 4,200 million Yuan (RenMinBi) in 1978, 8,190 million Yuan in 1988, 36,930 million Yuan in 1992 ( $\mathrm{Li}, 1994$ ), and 43,800 million Yuan in 1994 (CSN, 1994). According to the survey on top managers of SOCs conducted in August, 1994 based on the fourteen government departments there were only $60.1 \%$ profit-making SOCs in China, and $26.2 \%$ of SOCs were in under-capacity operation (FMDCG,
1995).

The heavy losses of SOCs hinder the progress in China's economic reform. There are many reasons to explain this result. (1) The property ownership given to the SOC is not clearly articulated thus prohibiting SOCs from utilizing capital assests in an efficient manner. (2) The management authorities of SOCs have not been transferred wholly yet from the central government to the SOC managers. (3) The functions and behaviors of the government (or the Communist Party) have not changed fundamentally, with the influence of Party secretaries still controlling majoy decisions in SOCs. In addition, (4) Chinese managers in charge of running SOCs are lacking managerial skills, especially those for excercising a decentralized leadership style, thus keep failing to encourage participation of rank-and-file employees in the processes of corporate performance.

For the most SOCs, their basic orientations involving economic, political, social, and technological environments remain almost unchanged for the past decade. Nonetheless, many SOCs do have made a great progress and achieved large profit, based on their successful internal managerial transformation, conducted by a group of skillful managers. It will be useful to understand that corporate human resource systems serve two basic control functions: one for controlling managerial processes by properly organizing critical people's abilities and role behaviors, and the other for developing the organization through cultivating people's capabilities within the corporation (Wakabayashi, 1994). Kornai (1986) pointed out that the Chinese economic reforms have looked to an enlargement of corporate management decision making authorities through the introduction of two main responsibility systems. One is the corporate responsibility system, which involved decentralization of decision making authorities from the government bureaus to the corporation level, by delegating the authority to establish business objectives in exchange for the responsibility to attain them. The other is the director responsibility system, which called for the director of a corporation to assume full authority for 
the operation and staffing, being free from the Party Committee's permission in exchange for the responsibility to achieve the set profit goals. This opened the way for the decentralization of decisions within corporate management structure for the realization of objectives at director's discretion (Child \& Lu, 1990). Research results showed that the participative decision making system had very positive effects upon management behaviors, and that the average level of participative decision making was higher in China than similar studies in other countries (for example Wang, 1989). Power and participation in managerial decision making are important factors in organizational effectiveness (Heller \& Wilpert, 1981; Wang, 1991). The key idea of decentralization is that the sharing of information and responsibility will enhance both the acceptance of decisions and job satisfaction among members. Heller (1991) pointed out that participation is not only as a strategy to improve decision performance, but also as a way to develop participants' competence, which in turn leads to more participation in organizational processes.

The objectives of this study are to explore factors which stands in the way towards decentralized leadership practices in Chinese SOCs: (1) to understand the demongraphic characteristics of contemporary Chinese managers in SOCs, (2) to identify leadership types (decentralized vs. centralized) used by these managers of SOCs, and (3) to analyze how the observed leadership type works to shape the leader-member exchange relations. Finally, (4) the relationship between decentralized leadership structure and corporate performance will be explored based on the 12 SOCs sampled in Zhejiang Province, China. In view of the present stage of organizational development, the hypotheses to be explored in this study involving the decentralized decision making practice in Chinese SOCs can be stated as follows.

Hypothesis 1. Since the economic reform has made a great progress in Chinese SOCs since 1978, it can be expected that the demographic composition of managers in SOCs has changed: with more colloge graduates occupying managerial posi- tions after the Cultural Revolution.

Hypothesis 2. Managers in high performing SOCs (state-owned corporations) are expected to have more decentralized leadership types than those in the average performing SOCs.

Hypothesis 3. In high performing SOCs, the quality of leader-member exchange relations is expected to be better than the one in average perforning SOCs. In other words, it is expected that in high performing SOCs managers are given by their superiors not only support, understanding and trust, but also more opportunities for decision making, compared with those in the average performing SOCs.

\section{METHOD}

\section{1) Subjects}

Twelve (12) state-owned corporations (SOCs) in manufacturing industry with different sizes were surveyed in two cities (Hangzhou and Shaoxing) of Zhejiang Province, China. There are three groups of subjects who responded questionnaires across these organizations, namely Top managers $(\mathrm{T}, \mathrm{n}=52)$, Middle managers $(\mathrm{M}, \mathrm{n}=99)$, and Lower-Middle managers ( $\mathrm{LM}, \mathrm{n}=59)$. The top managers consisted of directors or vice-directors of the corporations, most of whom participated in the management training course provided by the Hangzhou University during the survey period. The middle managers consisted of section managers, while the lower-middle managers consisted of assistant section managers of sections covering personnel, research and development, technology, sales, and administration areas. Objectives of the survey were explained to the top managers at each SOCs in order to win their understanding and support for administering the questionnaire survey with managers in respective corporation. During the survey period, all managers in the corporation ranging from the top to the middle and lower-middle managerial levels were asked to respond the questionnaire. In total, 218 managers were asked to fill out the questionnaires. Among them, 8 questionnaires could not be used because of some incomplete responses. Thus, the final number of subjects used for the present analysis 
are 210 , with their age ranging from 24 to 61 , including 147 male and 63 female managers.

For the purpose of testing hypotheses, two kinds of SOCs were sampled for the present study. One is a group of high performing SOCs, and the other is average performing ones. Prior to the sampling of SOCs, a series of interviews with the local government bureau in charge of supervising each SOC were conducted. Bureau officials provided researchers with a list of high and average performing SOCs, classified in terms of the average salary level of employees. If the average annual income of employees in the corporation exceeded 8,000 Yuan (RenMinBi), then that corporation was classified into a high performing SOC group, otherwise it was classified into the average performing group. Since the financial data of the SOCs are not disclosed publicly in China, the corporation's average wage was used as an approximation to the corporate performance. Based on this criterion, 4 SOCs sampled for this survey were classified into the high performing group, while the other 8 SOCs into the average performing group. The high performing SOCs consist of Hangzhou General Refrigerator Factory, Hangzhou Watch Factory, Shaoxing Bicycle Factory and Shaoxing Zhejiang Polyester Fiber Factory. All of them are not only high profit and high paying SOCs, but also the highly technical corporations with using a whole set of equipment introduced from abroad or using the most advanced equipment purchased within China. On the other hand, the average performing SOCs consist of Hangzhou First Txtile Mill, Hangzhou Zhejiang Flax Mill, Hangzhou Electric Motor Factory, Hangzhou Instrument Plant, Hangzhou Machine Tool Plant, Hangzhou Zhejiang Electric Engineering Company and Shaoxing Cardboard Box Factory. Among them, only Hangzhou Instrument Plant is considered to be a high-tech corporation, and all others are low-tech ones mainly operating based on the old domestic technology.

The decision to use the average annual wage level as an approximation to corporate performance can be rationalized by the fact that the annual wage in Chinese SOCs is a combination of the basic salary which is very low being set at the only subsistence level, and bonus which differs to a greater extent reflecting the corporation's paying ability. This means that unless a SOC can keep a substantial amount of after-tax profit, only a little resource would be left available for distributing bonuses among employees. On the other hand, the high profit making SOCs can afford to give out a greater portion of after-tax profit to their employees without being bothered by the burdon of allocation in the form of stock dividend. Therefore, the average annual wage consisting of basic salary and bonus can be a good approximation to the corporation's business performance in China.

\section{2) Measures}

Two sets of questionnaires were used: one for the top managers, and the other for the middle and lower-middle managers. Both of the questionnaires contained the same items, but with slightly different instructions between top and the other managers.

The questionnaires contained 15 items for measuring leader-member exchange relations (Graen, 1976; Graen and Wakabayashi, 1990) and a singleitem scale to identify superiors' leadership types (Chen, 1993).

The leader-member exchange measure asked: (1) the top managers to evaluate how frequently they themselves engage in behaviors involving exchange relations with their subordinates. On the other hand, (2) the middle and lower-middle managers were asked how frequently their immediate superiors engage in behaviors regarding exchange relations with the respondent managers. The same instruction was repeated for the leadership type item.

In other words, top managers responded the question items regarding their own exchange behaviors and leadership types directed toward their subordinates, while middle and lowermiddle managers did regarding exchange behaviors and leadership types involving their immediate superiors as perceived from their stand points.

The factor analysis conducted based on all subject managers showed that the leader-member 
Table 1 College graduates percentages at Top, Middle and LowerMiddle positions based on the three different generations in Chinese SOCs

\begin{tabular}{c|cccc}
\hline \hline Position & BCR & DCR & ACR & Total \\
\hline \multirow{2}{*}{ Top } & 70.6 & 75.0 & 100 & $75.0 \%$ \\
& $(12 / 17)$ & $(24 / 32)$ & $(3 / 3)$ & $(39 / 52)$ \\
Middle & 52.4 & 49.2 & 88.2 & $56.6 \%$ \\
& $(11 / 21)$ & $(30 / 61)$ & $(15 / 17)$ & $(56 / 99)$ \\
Lower-Middle & 63.6 & 46.9 & 68.8 & $55.9 \%$ \\
& $(7 / 11)$ & $(15 / 32)$ & $(11 / 16)$ & $(33 / 59)$ \\
\hline \multirow{2}{*}{ Total } & $61.2 \%$ & $55.2 \%$ & $80.6 \%$ & $61.0 \%$ \\
& $(30 / 49)$ & $(69 / 125)$ & $(29 / 36)$ & $(128 / 210)$ \\
\hline
\end{tabular}

Note: ACR (After Cultural Revolution) $=24-34$ years old, DCR (During Cultural Revolution) $=35-45$ years old, BCR (Before Cultural Revolution) $=46-61$ years old.

Figures in parentheses denote a number of college graduates (numerator) and an entry in each cell (denominator).

exchange measure consists of two factors, namely the support for subordinate and decision delegation factors. Summary results of the factor analysis is shown in Appendix. Using a Cronbach's alpha coefficient as an index of reliability, it was found that both the support for subordinate and decision delegation scales have sufficiently high reliability coefficients, with alpha $=.82$ and .65 , respectively.

The scale for leadership types asked the top managers to identify their own types of leadership out of 5 alternatives, ranging from the most centralized $(=1)$ to the most decentralized $(=5)$ as shown in Table 3. Also, they were asked to choose their preferred type of leadership as top managers. On the other hand, the middle and lowermiddle managers were asked to identify which type of leadership their immediate superiors are using on the job. Also, they were asked to respond which leadership type they like best to be associated with their superiors.

In addition, background variables, namely sex, age (generation), position in the organization, educational background were asked in the questionnaires.

\section{RESULTS}

\section{1) Demographic Characteristics of the Chinese Managers in SOC}

Since China started economic reform and open policy to the outside world in late 1970s, the pattern of managers' promotion in Chinese SOCs has undergone a major change. The present system, as opposed to the traditional one, no longer permit managers to be promoted simply based on their political background. Chinese government layed down a set of basic policies for developing the management organization by establishing the following guidlines regarding selection and promotion of potential managers. That is, the managers who will be promoted should be (1) young, (2) specialized in certain areas, (3) have a mastery of specific knowledge, and (4) be able to contribute to the democratization of the Chinese SOCs. Therefore, it is expected that after the application of these criteria since late $1970 \mathrm{~s}$, the structure of the Chinese management organization in terms of the managers' demographic composition changed considerably.

Table 1 shows the generation (age), educational background and position distributions of managers within SOCs sampled for our present study. The generation groups were derived by using ages corresponding to the beginning and ending years of the Cultural Revolution ${ }^{2)}$ in China. Namely, those whose age was 46-61 years old at the time of the present survey (1994) are classified into the

2) The Cultural Revolution began in 1966 and ended in 1976. 
Before Cultural Revolution (BCR) group, because they are those who graduated from high school or college (on or before 1965) and started to work before the start of the Cultural Revolution in 1966. They belong to the old generation and went through the ordeal of Cultural Revolution in full length. Likewise, managers who were $35-45$ years old at the time of survey (1994) are those who graduated from the school and started their work During Cultural Revolution (DCR, 1966-1976). Lastly, managers with age 24-34 years old in 1994 are those who graduated from school and started their work After Cultural Revolution (ACR, 1977 or thereafter). This tripartite grouping with respect to the Culture Revolution experiences seems plausible given the fact that the political and economic realities in China were completely different before, during and after Cultural Revolution, and thus demographic characteristics (especially age, educational backgrounds and status) of Chinese managers would be expected to differ significantly among these three generations.

The result of an analysis to examine the difference in demographic comparision among BCR, DCR and ACR groups are summarized as follows. The result of a series of $\chi^{2}$ analyses shows there are significant differences $\left(\chi^{2}=10.44, \mathrm{df}=4\right.$, $\mathrm{P}<.05$ ) among three manager groups with respect to their managerial positions achieved: namely, the older the generation, the higher the management positions achieved by them. The main differences come from the ACR managers who entered into the top management position relatively less and more into the lower-middle position. Since the younger generations lack experiences, they are more likely to remain at the lower-middle position, but contemporary Chinese SOCs seem to be nurturing young (ACR) managers starting at the low management level to replace older generations. This result shows a consistency with the government policy of promoting young managers from within the orgnization in Chinese SOCs. But it was found that the majority of middle and top management positions are still filled with the DCR or BCR generations, indicating some serious problems for the SOCs' efforts to transform its management organizations. Namely, (1) The age structure of the management organization within SOCs still preserves conservative ideologies undertaken by the BCR and DCR groups that dominate the top and middle management positions. (2) These groups may act against the reform initiatives. (3) They may be reluctant, or do not know how, to nurture well qualitied young managers who will become to replace themselves in the near future.

Results of $\chi^{2}$ analysis also indicate that in Table 1 there exist significant differences in educational background (college vs. non-college graduate) between the top and middle managers $\left(\chi^{2}=4.96, \mathrm{df}=1, \mathrm{P}<.05\right)$, and between the top and lower-middle managers $\left(\chi^{2}=4.41, \mathrm{df}=1\right.$, $\mathrm{P}<.05$ ). Among top managers, $75 \%$ of them completed higher education, while among middle managers and lower-middle managers only $57 \%$ and $56 \%$ did so respectively. It was found that the percentage of college graduates among top managers in Chinese SOCs $(75.0 \%$ for our sample managers) is not low relative to the one in other countries, for example $85 \%$ in USA, $62 \%$ in the old West Germany, and $24 \%$ in Britain in 1986 (Handy, 1988). This high percentage of the college graduate top management population in Chinese SOCs is mainly attributable to the policy of promoting the specialized and qualified (mastery of knowledge) managers to the top positions. In addition, increasing opportunities to get higher education in China, particularly through the management cadre training institutes and the TV University programs in China helped non-college graduate managers to acquire degrees from the higher educational institutions. Table 1 indicates that even the majority of old generation managers belonging to the BCR group could afford completing higher education. Table 1 also indicates that for the $\mathrm{DCR}$ and $\mathrm{ACR}$ groups college graduate percentages become smaller at the middle and lower-middle management levels, showing that more and more non-college employees are occupying managerial positions at these levels relative to the top level. This is particularly true for the Middle group. 
During the Cultural Revolution, the majority of our DCR group managers (those in their twenties during the 1966-76 period) could not finish even the middle school. During that period, all university students were recruited from among workers in SOCs, farmers in the village and soldiers, who were therefore called worker-, peasant-, and soldier-university students, respectively. There were no entrance examinations given to screen applicants and the only criterion for giving admissions was their political background. Since 1977, after the end of the Cultural Revolution, however, the Chinese universities were made open to the whole population. Every young people in the relevant age cohort had the right to enter a university, if he could have passed the entrance examination which made available for all high school graduates. Since then, the higher education in China has gradually become normalized and the number of college graduates kept increasing year after year. Therefore, it is expected that from now on the ACR college graduates will move up in the organization to replace old generation managers at all management levels in SOCs.

This trend can be suppored by the result of $\chi^{2}$ analysis that produced a significant difference $\left(\chi^{2}=7.56, \mathrm{df}=2, \mathrm{P}<.05\right)$ regarding the educational background among $\mathrm{ACR}, \mathrm{DCR}$, and BCR managers. The main source for the significant $\chi^{2}$ value obtained comes from the ACR generetion where $80.6 \%$ of managers are college graduates, while for the $\mathrm{DCR}$ and $\mathrm{BCR}$ generations, the percentages are $55.2 \%$ and $61.2 \%$, respectively. The above result provides evidence to support Hypothesis 1 , indicating that the educational background of managers in Chinese SOCs has changed since the start of the open economic policy.

Table 2 shows the distribution of managers by sex and the position level. The result of a $\chi^{2}$ analysis shows that the sex difference in frequency distribution is significant $\left(\chi^{2}=7.06, \mathrm{df}=2\right.$, $\mathrm{P}<.05$ ), with the majority of top managers (88.5\%) being male, while at the middle and lower-middle levels only $67.7 \%$ and $57.6 \%$ are male, respectively. The percentage of female managers increases significantly with the managerial level decreasing. It needs to be emphasized that the percentage of female managers observed in our sample as a whole is considered high relative to the world standard. The result indicates that rapid economic expansion and the goverment policy to mandate equal labor force participation between male and female in China have offered opportunities for women to be managers in SOCs (Adler \& Izraeli, 1994).

As a result of sixteen years reform efforts, new management structure emerged gradually in Chinese SOCs. The selection policy based on the four basic criteria, which says the managers should be young, specialized, masters of knowledge, and contributing to the democratization of management organizations, seems working in Chinese SOCs. Yet, there are still many structural problems left unsolved. For example, in a large sample survey conducted in 1994 by fourteen ministries and commissions under the State Council of China, it was found that $86.0 \%$ of top managers in SOCs are still politically appointed by the government, although this percentage is much lower in collectively owned corporations (58.4\%), joint-

Table 2 Distribution of sample managers by sex and position

\begin{tabular}{|c|c|c|c|c|}
\hline Sex & Top & Middle & Lower-Middle & Total \\
\hline Male & $\begin{array}{c}46 \\
(88.5)\end{array}$ & $\begin{array}{c}67 \\
(67.7)\end{array}$ & $\begin{array}{c}34 \\
(57.6)\end{array}$ & $\begin{array}{c}147 \\
(70.0)\end{array}$ \\
\hline Female & $\begin{array}{c}6 \\
(11.5) \\
\end{array}$ & $\begin{array}{c}32 \\
(32.3)\end{array}$ & $\begin{array}{c}25 \\
(42.4)\end{array}$ & $\begin{array}{c}63 \\
(30.0)\end{array}$ \\
\hline Total & $\begin{array}{c}52 \\
(100 \%) \\
\end{array}$ & $\begin{array}{c}99 \\
(100 \%)\end{array}$ & $\begin{array}{c}59 \\
(100 \%)\end{array}$ & $\begin{array}{c}210 \\
(100 \%)\end{array}$ \\
\hline \multicolumn{2}{|c|}{$\chi^{2}=7.06$} & \multicolumn{2}{|c|}{$\mathrm{df}=2$} & \\
\hline
\end{tabular}


venture corporations (33.2\%), and share holding corporations (40.4\%). This indicates that the SOCs may still experience a very strong administrative interference exerted by top managers representing the central government.

\section{2 ) Leadership types among SOCs' managers}

The industrial reform policy started in 1979 enabled managers in SOCs to obtain more power delegated from the government and use it to cultivate more vigor in the management organization (Chen, 1993). Many Chinese corporations since then started to introduce Japanese as well as Western technologies and management methods (eg. QCC, TQC, Kaizen, job analysis, performance evalution, $\mathrm{MBO}$, and management training, etc.). However, the question remains regarding the extent by which the Chinese managers are actually allowed to use this power in introducing technologies and management methods for the purpose of achieving goals of their corporations. It is expected that only under the demoncratic or decentralized leadership structure the delegated power would be used properly and produce results at the individual corporate level, because employees' participation in the process of goal achievement would only be made possible under the decentralized leadership structure. Especially, it is expected that successful operation of advanced management methods and production technologies in Chinese SOCs must be associated with managerial practices derived from decentralized leadership structure.

Table 3 gives descriptions of five different leadership types used to categorize managers sampled for the present study. Each descriptive type is arranged in order of the degree of decentralization. For testing reliability of this rank-order scale, a survey was conducted asking respondents to place each type in decending order from the most decentralized (No. 5) to the least decentralized (or the most centralized, No. 1). The result of this survey indicated that respondents agree highly with respect to the ranking order of each type (overall agreement is $92 \%$ ), and that each type described in Table 3 represents an anchor point along the Centralization-Decentralization leadership scale (Chen, 1993).

Table 4 presents Chinese managers leadership types judged by the top, middle and lower-middle managers in SOCs sampled for the study. In each SOC, top managers were asked to report their own leadership type, while the middle and lowermiddle managers reported their superior's leadership type by using the five category scale shown in Table 3. Table 4 reports a significant difference $(\mathrm{P}<.05)$ found in cognition of leadership types among the three manager groups, particularly

Table 3 Descriptions of five leadership types: Centralized-Decentralized

\begin{tabular}{c|l}
\hline \hline \multicolumn{1}{c|}{ Type } & \multicolumn{1}{c}{ Description } \\
\hline 1 Very Centralized & $\begin{array}{l}\text { Generally makes a decision quickly and transmits it to subordinates clearly } \\
\text { and firmly, asks them to implement the decision faithfully, and do not put } \\
\text { forward difficult questions. }\end{array}$ \\
\hline 2 Centralized & $\begin{array}{l}\text { Generally makes a decision resolutely, and explains it to subordinates as far } \\
\text { as possible, presents reasons for carrying out the decision, and answers their } \\
\text { questions before implementing it. }\end{array}$ \\
\hline 4 In Between & $\begin{array}{l}\text { Generally seeks subordinates' opinions of a decision before making the final } \\
\text { one, announces the decision after listening to and thinking over subordinates' } \\
\text { opinions. Subordinates must implement the decision faithfuly whether it } \\
\text { coincides with their opinions or not. }\end{array}$ \\
\hline 5 Very Decentralized & $\begin{array}{l}\text { Generally puts forward problems and discusses them with subordinates before } \\
\text { making an important decision, and takes the opinions put forward by } \\
\text { majority of subordinates as the final decision. }\end{array}$ \\
\hline
\end{tabular}


Table $4 \chi^{2}$ analysis on Chinese managers' leadership types judged by the top, middle, and lower-middle managers of SOCs

\begin{tabular}{c|cccc}
\hline \hline Type & Top & Middle & Lower-Middle & Total \\
\hline \multirow{2}{*}{ Centralized } & 14 & 52 & 30 & 96 \\
& $(26.9)$ & $(52.5)$ & $(50.8)$ & $(45.7)$ \\
In between & 17 & 27 & 18 & 62 \\
& $(32.7)$ & $(27.3)$ & $(30.5)$ & $(29.5)$ \\
Decentralized & 21 & 20 & 11 & 52 \\
& $(40.4)$ & $(20.2)$ & $(18.6)$ & $(24.8)$ \\
\hline \multirow{2}{*}{ Total } & 52 & 99 & 59 & 210 \\
& $(100 \%)$ & $(100 \%)$ & $(100 \%)$ & $(100 \%)$ \\
\hline \multicolumn{2}{c}{$\chi^{2}=12.89$} & & $\mathrm{df}=4$ & $\mathrm{P}<.05$ \\
\hline
\end{tabular}

Note: "Centralized" includes Type 1 and 2 shown in Table 3, while "In between" and "Decentralized" consist of Type 3 , and Type 4 and 5 combined, respectively.

between the top, and the middle and lower-middle managers. Namely, the top managers themselves tend to perceive their own leadership types more decentralized, while the middle and lower-middle managers see their superiors' leadership types rather centralized. Generally speaking, the top manager's position power has been enhanced since reform started. According to the result shown in Table 4, only a quarter top managers (about 27\%) identify themselves to have centralized leadership, while the rest of them share the increased authority with subordinate managers either through decentralized leadership (about $40 \%$ ), or remaining neutral in between the two extreme types (about 33\%). On the other hand, the majority of middle (52.5\%) and lower-middle (50.8\%) managers perceive their superiors' leadership more centralized in their decision making process. Only $20.2 \%$ and $18.6 \%$ of middle and lower-middle managers respectively think their superiors are practicing decentralized leadership style. This result may indicate frustration among the middle and lower-middle managers, due to the lack of participation opportunities in the processes of decision making. This finding is consistant with the result reported by Chen (1993) in which middle managers and technicial workers in SOCs in China evaluated their superiors' leadership to be centralized, and also indicated frustration with their leadership styles. Compared with leader behaviors in the management organization of developed nations, the Chinese tradition may still encourage its managers to resort to centralized decision making. However, variations may exist within China. For example, in the modernized industrial sector, or among successful SOCs, Chinese managers were reported using more participative methods (Xu, 1994).

To test the hypothesis that in successful SOCs managers may practice decentralized decision making more frequently than managers in the average performing SOCs, the decentralization score was derived by converting a type score into a numerical value, i.e., by giving a value ' 5 ' to the most decentralized type (No. 5 in Table 3 ), ' 4 ' to the next, and ' 3 ', ' 2 ' and ' 1 ' to the remaining types respectively in order of the degree of decentralization. Based on this score, a series of t-test were conducted to explore if managers in high performing SOCs are practicing more decentralized decision making relative to those in the average performing SOCs.

Results of the analysis shown in Table 5 are summrized as follows. (1) Overall, as shown in Figure 1, managers in high performing corporations tend to have superiors with more decentralized decision making style relative to those in average performing corporations. Then, scores that indicate a superiors' decentralized leadership style were found significantly different between high and average performing firms (3.07 and 2.53, $\mathrm{t}=2.93, \mathrm{P}<.05$ ). (2) In average performing SOCs, 
Table 5 The Chinese managers' decentralization scores evaluated based on Position and Corporate Performance, and results of t-test

\begin{tabular}{|c|c|c|c|c|c|c|c|c|}
\hline \multirow{2}{*}{$\begin{array}{l}\text { Corporation } \\
\text { Performance }\end{array}$} & \multicolumn{5}{|c|}{ Position } & \multicolumn{3}{|c|}{ t-test on Position } \\
\hline & \multicolumn{2}{|c|}{ Total } & Top & Middle & $\begin{array}{l}\text { Lower- } \\
\text { Middle }\end{array}$ & $\mathrm{T} / \mathrm{M}$ & $\mathrm{T} / \mathrm{LM}$ & $\mathrm{M} / \mathrm{LM}$ \\
\hline \multirow{3}{*}{ Total } & M & 2.67 & 3.17 & 2.49 & 2.53 & & & \\
\hline & $\mathrm{SD}$ & 1.26 & 1.17 & 1.30 & 1.16 & $3.14^{* *}$ & $2.86^{* *}$ & .19 \\
\hline & $\mathrm{N}$ & 210 & 52 & 99 & 59 & & & \\
\hline \multirow{3}{*}{ High Performance } & M & 3.07 & 3.29 & 2.77 & 3.78 & & & \\
\hline & SD & 1.50 & 1.49 & 1.56 & 1.09 & 1.03 & .81 & 1.77 \\
\hline & $\mathrm{N}$ & 54 & 14 & 31 & 9 & & & \\
\hline \multirow{3}{*}{ Average Performance } & $\mathrm{M}$ & 2.53 & 3.13 & 2.37 & 2.30 & & & \\
\hline & SD & 1.14 & 1.04 & 1.16 & 1.04 & $3.32^{* *}$ & $3.67^{* * *}$ & .34 \\
\hline & $\mathrm{N}$ & 156 & 38 & 68 & 50 & & & \\
\hline \multicolumn{2}{|c|}{$\begin{array}{l}\text { t-test on Performance } \\
\text { (High/Average) }\end{array}$} & $2.93^{*}$ & .43 & 1.26 & $3.24^{* *}$ & & & \\
\hline
\end{tabular}

Note: * $\mathrm{P}<.05, \quad * * \mathrm{P}<.01, \quad * * * \mathrm{P}<.001$.

The degree of decentralization is measured by 5 -point scale. Score 5 means the most decentralized leadership type, while score 1 the least decentralization (or the most centralization).

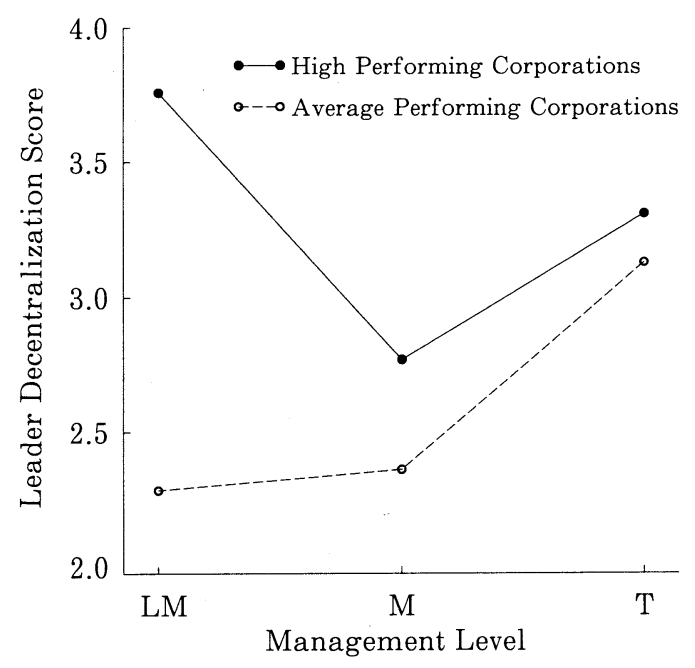

Figure 1 The leader decentralization score for the top, middle and lower-middle managers

Note: $\mathrm{LM}=$ Lower-Middle managers, $\mathrm{M}=$ Middle managers, and $\mathrm{T}=$ Top managers

the middle and lower-middle managers have superiors with more centralized decision making style (2.37 and 2.30 respectively), compared with their colleagues in high performing SOCs (2.77 and 3.78 respectively). Particularly, at the lower- middle level decentralization scores were significantly different: 2.30 vs. 3.78 for average and high performing SOCs respectively $(\mathrm{t}=3.24, \mathrm{P}<.01)$. (3) In average performing SOCs, significant differences on the scores of decentralization were found between the top and middle (3.13 vs. $2.37, \mathrm{t}=3.32$, $\mathrm{P}<.01$ ), and lower-middle managers (3.13 vs. 2.30 , $\mathrm{t}=3.67, \mathrm{P}<.001$ ). In summary, a lack of decentralized leadership seems to be the problem in the average performance SOCs in China. Particularly, this problem may become serious in the middle and lower-middle management levels where managers at each level must deal with superiors who are not quite willing (just 'in between') to decentralize decision making authorities to their subordinate managers. Especially, this problem must be serious at the lowermiddle level in the average performing SOCs as shown in Figure 1.

The ANOVA test on the leader decentralization score conducted based on corporate performance, High vs. Average, and the management level, Middle vs. Lower-middle (but top managers who reported on their own decision making style were omitted), produced a result to support the above 
findings. Namely, in addition to the main effect of Position $(\mathrm{F}=4.47, \mathrm{P}<.01)$ and Performance $(\mathrm{F}=10.44, \mathrm{P}<.001)$, the interaction effect between Position and Performance turned out to be significant $(\mathrm{F}=2.98, \mathrm{P}<.05)$, indicating that leader decentralization is particularly high at the lowermiddle level in the high performing SOCs as shown in Figure 1. This result implies that one of the features of high performing SOCs in China is the highly decentralized leader behaviors at the lower-middle management level, where subordinate managers can enjoy the high level participation in decision making processes.

\section{3) Leader-subordinate exchange relations in Chinese SOCs}

The quality of leader-member exchange has proven to be an critical factor in determing the members job performance and managerial progress in the organization (Graen, 1976; Wakabayashi and Graen, 1984, 1990). For the present study, the original Leader-Member Exchange Scale used by Wakabayashi and Graen (1986) was employed, by adding several items to incorporate some unique aspects associated with the Chinese leader-subordinate relations on the job.

As shown in Appendix, the result of the factor analysis conducted by using the principal factor solusions with Varimax rotation produced two factors. The first support for subordinate factor indicates leader's behaviors for supporting his subordinate with respect to morale as well as instrumental aspects on the job. On the other hand, the second decision delegation factor suggests that the leader high with this dimension will provide his subordinate with authority to decide on his job without asking permission. Reliability coefficients (Cronbach's alpha coefficients) calculated for the support for subordinate and decision delegation factors turned out to be .82 and .65 respectively, indicating satisfactorily high internal consistency for each factor. The above results indicate that for promoting decentralization within the context of leader-member exchange in the organization, parties to this relationship must work for empowering subordinate roles by providing superior's support and strengthening subordinate's decsion autonomy. The mean scores of support for subordinate and decision delegation for the sample managers are shown in Table 6 .

Figure 2 shows that the decision delegation level of high performing SOCs' managers is higher than that of average performing SOCs' managers. The higher the management level (from the lowermiddle to top level), the greater the difference between high and average performing corporations. Results of a series of t-test show that there is a significant difference of decision delegation between the top managers in high performing

Table 6 Scores of Support for Subordinate and Decision Delegation for managers at three different levels (LM, M and T) in High and Average performing corporations

$\mathrm{N}=210$

\begin{tabular}{l|cccc}
\hline \hline & $\begin{array}{c}\text { Total } \\
\text { M (SD) }\end{array}$ & $\begin{array}{c}\text { LM } \\
\text { M(SD) }\end{array}$ & $\begin{array}{c}\text { M } \\
\text { M (SD) }\end{array}$ & $\begin{array}{c}\text { T } \\
\text { M (SD) }\end{array}$ \\
\hline Support for Subordinate & & & & \\
High Performance & $3.17(.69)$ & $2.99(.73)$ & $3.04(.67)$ & $3.59(.46)$ \\
Average Performance & $3.15(.79)$ & $2.93(.80)$ & $3.03(.83)$ & $3.63(.41)$ \\
Total & $3.15(.76)$ & $2.94(.79)$ & $3.04(.78)$ & $3.62(.42)$ \\
\hline Decision Delegation & & & & \\
High Performance & $2.66(.69)$ & $2.29(.88)$ & $2.60(.59)$ & $3.01(.63)$ \\
Average Performance & $2.36(.76)$ & $2.26(.76)$ & $2.33(.76)$ & $2.56(.72)$ \\
Total & $2.44(.75)$ & $2.26(.77)$ & $2.41(.72)$ & $2.68(.72)$ \\
\hline
\end{tabular}

Note: $\mathrm{LM}=$ Lower-Middle $(\mathrm{n}=59), \mathrm{M}=$ Middle $(\mathrm{n}=99), \mathrm{T}=$ Top $(\mathrm{n}=52)$. 


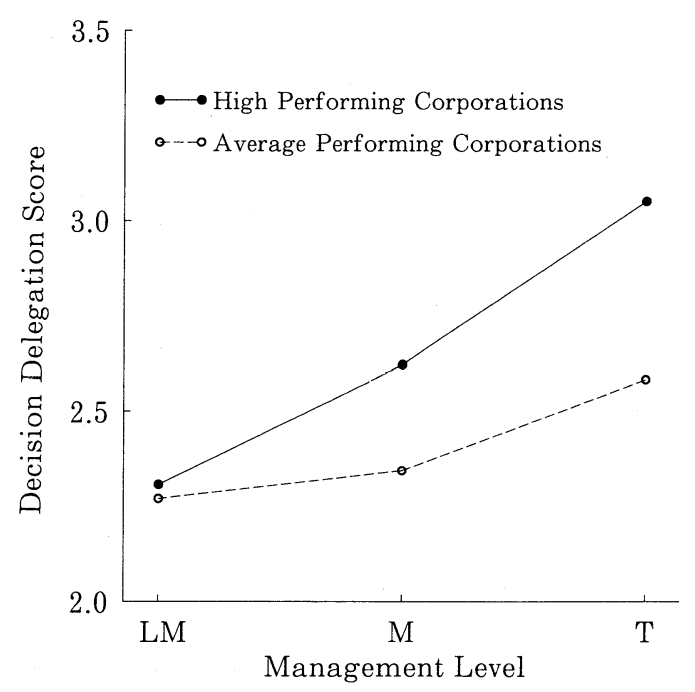

Figure 2 The decision delegation scores for the top, middle and lower-middle managers

SOCs and average performing ones $(t=2.03$, $\mathrm{P}<.05$ ). This indicates that the top managers in high performing SOCs pass down more decision making power to the middle and lower-middle management levels than those in average performing SOCs.

For the next step, the two-way ANOVA based on the Position, Lower-middle vs. Middle (but Top managers who were asked to report their own behaviors were omitted), and Performance, High vs. Average, was conducted to examine the impact of these sources upon mean differences in the quality of leader-member exchange evaluated in terms of two factors discussed above. The hypothesis for this analysis states that both Position and Performance will show significant positive effects upon support for subordinate and decision delegation, suggesting that managers with the higher positions, and those working for the high performance SOCs are enjoying higher quality of leader-member exchange relations relative to other managers.

The result of ANOVA indicates that as hypothesized the position has a significant effect on both support for subordinate $(\mathrm{F}=14,93, \mathrm{P}<.001)$ and decision delegation $(\mathrm{F}=4.69, \quad \mathrm{P}<.01)$ by the leader. However, the performance effect was found significant only for decision delegation $(F=3.90$, $\mathrm{P}<.05$ ), indicating that managers in high performing SOCs are more likely to have higher level decision delegation given by their superiors relative to these in the average performing SOCs. This result supports the result of the t-test shown in Table 5. The combined Position by Performance effect was found non significant statistically.

Before economic reform, managers in SOCs had little power to handle their own businesses. They were controlled by the political bureau above them through the administrative commands. As a result of industrial management reform since 1978, the old structure based on the state ownership and administrative control has been transformed into diversified economic and management structures (Xu, 1989). At the present stage of reform development, corporate leaders are entitled to use more power than they were allowed to do previously. As a result, corporate leaders are now very willing to build their own management styles and to develop organizational vigor in each corporation (Chen, 1993). With the advancement of reform and opening of Chinese economy to the outside world, a variety of new ideas and advanced managerial theories and methods have been introduced into SOCs in China. Now, many ambitious managers have realized the importance of enhancing managerial skills to develop their organizations to cope with the changing environment. However, the management style in Chinese SOCs is still dominated by the centralized or 'in-between' leadership types. The Chinese government has also realized that the centralized leadership structure in management is a hindrance to the reform efforts in SOCs, especially in average or low performing SOCs. The present analysis suggests that in the modernized and high performing SOCs, the decentralized leadership style seems working, but in the majority of 'average' SOCs, decentrlization in management must go a long way.

According to the results shown in Figure 1, the lower-middle management is the main source of variance in explaining the position effect on decentrlized leadership. It is evident that in high performing corporations the decision making 
authority is passed down to the middle and lowermiddle level managers. It is expected that the lower-middle managers in high performing SOCs maintain high involvement in their work and feel responsible to do their jobs well with the support and decision delegation provided by their superiors. Then, their involvement may work to facilitate more successful performance of their corporate business.

Currently, both centralized and decentralized management styles are operating in Chinese SOCs. The development of decentralized management structure is in its initial stage, and the pace of management development is very different among corporations. At the beginning stage of corporate reform, most of the SOCs used the centralized method to control their organizations and businesses. It is true that the centralized control actually helped the corporation's development in the turbulent and unpredictable environment at the initial stage of economic reform. In addition, the quality of labor force was low and structure of leadership at the middle and lowermiddle level of the organization was in a state of disunity in the beginning. However, with the development of the economy and corporate businesses, and with the deepening industrial reform producing a steady progress, the corporate environment has changed: the employee's income and living standards have remarkably enhanced, their working conditions have been improved, and workers initiative and motivation to work have been strenthened. Given the present stage of economic development, if the leadership structure within the Chinese SOCs were to remain with the traditional centralized style, then they would become outdated and loose relevance with the demands of the environment and needs of the employee as well. Employees working for the centrally managed (and average performing) SOCs may feel dissatisfied very easily as the economic development continues, and the corporate performance become worse and worse. It is under this contingency that the introduction of more decentralized management is highly recommended for the Chinese SOCs.

\section{CONCLUSIONS}

Currently, the Chinese government is paying more attention to HRM in the SOCs. The quality of managerial talents has improved partly in recent years, since the SOCs have been nurturing the young managers who started at the lower level after Cultural Revolution and were trained to take resposibilities at the middle and lower-middle level of management. The result of our study revealed that the percentage of college graduate at the top management level is very high (75\%). Male managers with university degrees seem to have higher probability to be promoted to the top management position in Chinese SOCs, although the share of female managers was found very high at the middle and lower-middle levels. It is interesting to find that a series of analyses conducted to examine the effect of generational differences of managers (namely, BCR, DCR and ACR groups) produced no significant results with respect to decentralization and leader-member exchange relations. This result suggests that the manager's position in the organization rather than the generational difference has stronger impact upon leader behaviors involving decentralization and leader-member exchange relations with respect to support for subordinate and decision delegation. Also, it was found that in the successful SOCs, managers employ decentralized decision making more often and engage in the higher level leadermember exchange relations than those in the average performing SOCs. In recent years, power of the top managers in SOCs is getting stronger and stronger. This trend reflects a government policy to separate politics from corporate management, bringing more resources and influence to leaders in SOCs. But if top managers retain all the power without sharing it with middle and lower-middle managers, it is not quite a blessing for development of the management organization within the corporation. At the present stage of Chinese economic development, there exists a strong need for passing down the power from the top to the middle and then to the lower-middle managers, so that young and more educated 
managers would be given opportunities to participate in the decision making processes within the state-owned corporations in China. Therefore, the top managers should be encouraged to adopt more decentralized leadership styles to enhance participation of young managers at the middle and lower-middle positions. Also, managers in SOCs through out the organizational hierarchy need to acquire leader-member exchange skills through the management development training, so that they can implement the concepts of support for subordinate and decision delegation to get their jobs done by working together with their subordinates.

\section{REFERENCE}

Adler, Nancy., and Dafna Izraeli (1994) Competitive Frontiers: Women Managers in a Global Economy, Cambridge, MA: Blackwell.

Chen, Ziguang (1993) The differences in Cognition of Top Managers' Leadership Types in Chinese Enterprises: On Cognitive Differences among Top Managers, Middle Managers and Technicians, Japanese Journal of Administrative Behavior, 8(2): 107-112.

Chen, Ziguang (1993) The Differences in Estimation of Interpersonal Relations and the Importance of Intellectuals among Three Kinds of People in Enterprises, Acta Psychology Sinica, Vol. 25, No. 1.

Child, John, and Yuan Lu (1990) Industrial Decision-Making under China's Reform, 1985-1988, Organization Studies, 11: 321-351.

Chinese Science News-Overseas Edition, 1995, 3, 25.

Fourteen Ministry Departments of Chinese Government (1995) A Survey on Chinese Enterpreneurs in 1995.

Graen, G. B. (1976) Role Making Processes within Complex Organizations, in M. D. Dunnette (ed.), Handbook of Industrial and Organizational Psychology, Chicago: Rand McNally Publishing.

Handy, Charles (1988) The Quest, in Charles
Handy, Colin Gordon, Ian Gow, and Collin Randlesome (eds.), Making Managers, Bath: Pitman Publishing.

Heller, Frank A., P. D. J. Drenth, P. Koopman, and V. Rus (1991) Decision-Making and the Under-utilization of Competence, in F.A. Heller (ed.), Decision-Making and Leadership, Cambridge: Cambridge University Press.

Heller, Frank A., and B. Wilpert (1981) Competence and Power in Managerial DecisionMaking, Chichester: John Wiley \& Sons.

Kornai, Janos (1986) The Hingarian Reform Process: Visions, Hopes and Reality, Journal of Economic Literature, 24: 1687-1737.

Li, Chengrui (1994) The Reform of State-Owned Corporation: To Rationalize the Relation of the Possession of Property and Transfer the Management Mechanism, Chinese Social Science, No. 2.

Pieper, Rüdiger eds. (1990) Human Resource Management: An International Comparison, Berlin: Walter de Gruyter.

Statistics Yearbook of China, 1993, 1994.

The Tokai Kokusai Shimbun, 1995, 8, 15.

Wakabayashi, Mitsuru (1994) Cross-cultural research in China: Re-discovering how to do business, Mimeographed paper.

Wakabayashi, M., and G. B. Graen (1984) The Japanese Career Progress Study: A 7-year Follow-up, Journal of Applied Psychology, 69, 603-614.

Wakabayashi, Mitsuru, and George Graen (1989) Human Resource Development of Japanese Managers: Leadership and Career Investment, Research in Personnel and Human Resources Managment, Suppl. 1, 235-256, JAI Press INc.

Wang, Zhongming (1989) Participation and Skill Utilization in Organizational DecisionMaking in Chinses Enterprises, in B.J. Fallon, H. P. Pfister and J. Brebner (eds.), Advances in Industrial Organizational Psychology, pp. 19-26, Amsterdam: Elsevier Science Publishers BV.

Wang, Zhongming (1990) Human Resource Management in China: Recent Trends, in Rüdiger 
Pieper (eds.), Human Resource Management: An International Comparison, Berlin: Walter de Gruyter.

Wang, Zhongming, (1991) Recent Development in Industrial and Organizational Psychology in the People's Republic of China, in C. L. Cooper, and I. T. Robertson (eds.), International Review of Industrial and Organizational Psychology, Vol.6:1-15.

Warner, Malcolm (eds.) (1987) China's Management Reforms, London: Frances Printer.
Xu, Lianchang (1989) Chinese Management Style, in B. J. Fallon, H. P. Pfister, and J. Brebner (eds.), Advances in Industrial Organizational Psychology, Amsterdam: North-Holland, Elsevier Science Publishers BV.

Xu, Lianchang (1994) Cross-cultural Studies of Leadership in Time of Economic Reform, Paper Presented at the Workshop in Beijing, China.

(平成 7 年 11 月 10 日受稿, 平成 7 月 12 月 10 日受理) 


\section{Appendix}

The result of a factor analysis on the leader-member exchange measure evaluated by Chinese managers in the state-owned corporations

\begin{tabular}{|c|c|c|c|c|c|}
\hline \multirow{2}{*}{ Item } & \multicolumn{5}{|c|}{$\mathrm{N}=210$} \\
\hline & M & $\mathrm{SD}$ & $\mathrm{F} 1$ & $\mathrm{~F} 2$ & $\mathrm{~h}^{2}$ \\
\hline F1: Support for Subordinate & 3.15 & .76 & $\alpha=.82$ & & \\
\hline 14. Superior understands my working situations & 3.30 & 1.01 & .66 & .13 & .45 \\
\hline 15. Superior has high work spirit \& ethical standards & 3.52 & 1.17 & .65 & .01 & .42 \\
\hline 11. Superior supports me to do a difficult job & 3.04 & 1.24 & .62 & .25 & .45 \\
\hline 8. Superior lets me do my job freely & 3.36 & 1.15 & .57 & .34 & .44 \\
\hline 2. Superior encourages me to make changes & 3.30 & 1.15 & .55 & .31 & .40 \\
\hline 12. Superior can offer me extra budget & 2.92 & 1.25 & .54 & .26 & .36 \\
\hline 5. Superior helps me to solve difficult problems & 3.11 & 1.07 & .46 & .15 & .23 \\
\hline 10. Talk freely with superior & 2.67 & 1.07 & .44 & .37 & .33 \\
\hline F2: Decision Delegation & 2.44 & .75 & & $\alpha=.65$ & \\
\hline 4. I can answer phone \& make decisions for superior & 2.57 & 1.11 & .20 & .59 & .39 \\
\hline 9. I can make a important decision for superior & 2.20 & 1.18 & .17 & .46 & .24 \\
\hline 1. Superior transmits important information to me first & 2.20 & 1.04 & .13 & .46 & .23 \\
\hline 3. Superior lets me do important work freely & 2.52 & 1.24 & .05 & .44 & .20 \\
\hline 13. Superior lets me do my work freely & 2.70 & 1.23 & .39 & .43 & .34 \\
\hline \multicolumn{6}{|l|}{ Residual items: } \\
\hline 7. Superior explains what is going on for me & 2.53 & 1.12 & .44 & .41 & .37 \\
\hline 6. Superior asks my help & 2.71 & 1.05 & .43 & .44 & .39 \\
\hline Variance explailed & & & 2.81 & 1.67 & 4.48 \\
\hline Percentage of variance explained & & & 21.62 & 12.85 & 34.46 \\
\hline
\end{tabular}

Note: The contents of the leader-member exchange measure shown here refer to the middle and lower-middle managers. 